IRSH 53 (2008), pp. 485-5 I I doi:I0.1017/So020859008003568

(C) 2008 Internationaal Instituut voor Sociale Geschiedenis

\title{
SURVEY
}

\section{The International Labour Organization (ILO) in Past and Present Research}

\author{
JASMIEN VAN DAELE*
}

SUMmaRY: This article addresses from a multidisciplinary perspective key questions, trends, and debates that have determined how the history of the International Labour Organization (ILO) has been conceived over the past ninety years. ILO historiography has to be understood in relation to the historical development of the ILO as an institution; the international political, economic, and social context; and the developments within the scientific discipline, especially the fields of (a globalizing) labour history and international relations/organizations. A starting point for this survey essay is the central hypothesis that the scientific interest in the history of international organizations is very much related to the general importance attached to multilateral structures and the belief in the effectiveness of international cooperation. Based on this analysis of the past trends and the current state of the field, I conclude with comments on lacunae and possible paths for future research on ILO history.

Studying the history of the International Labour Organization (ILO) is desirable for several reasons. Firstly, the ILO has been a trendsetter among international organizations in standard-setting (creating labour standards by means of conventions and recommendations) as well as in technical cooperation and international expertise on labour matters. By means of its operational activities in the field as part of this three-pronged action the ILO has tried to improve the daily working life of people worldwide. Secondly, the organization was (and still is) unique in its tripartite structure. Whereas all other international organizations (like the United Nations) consist exclusively of representatives of national states, the ILO brings together governments, employers and trade unions at all levels

\footnotetext{
* Research Officer "ILO Century Project", International Institute for Labour Studies-ILO, Geneva. The views expressed in this paper are solely those of the author and do not necessarily reflect any position of the ILO. I am grateful to Marcel van der Linden, Gerry Rodgers, and Dirk Luyten for their careful reading and useful suggestions.
} 
of decision-making. This combined structure of governmental and nongovernmental constituents has proved to be very stable as it has remained unchanged up to the present day. Thirdly, the ILO is the oldest international organization of the twentieth century. Founded in I919, the ILO will be ninety years old in 2009. The organization was established as the first specialized agency within the League of Nations. But unlike the League, the ILO survived World War II and became part of the succeeding United Nations (UN) system. ${ }^{\mathrm{I}}$ Since it is one of the very few international organizations with a lengthy and unbroken history, the ILO is an interesting research topic for historians.

So far, comprehensive academic reviews of the literature on ILO history have not yet been undertaken. This essay will try to fill this void. ${ }^{2}$ I will review the literature in order to trace the general evolution and the particular contours of ILO historiography. Since the early days a considerable body of literature has accumulated in many languages and I do not claim exhaustiveness here. This survey article is based on what I consider to be the most relevant and representative literature that has addressed key questions and reflects trends, debates, and developments that determine how the ILO has been conceived over the past ninety years and that help explain the current state of ILO history.

The conjunctures and (shifts in) analytical foci in ILO historiography have to be understood in relation to three broader aspects: the historical development of the ILO as an institution; the international political, economic, and social context; and developments within the scientific discipline, especially the fields of labour history and international relations/ organizations. A starting point for this survey essay is the central hypothesis, as stated by Louis Sohn, that scientific interest in the history of international organizations is very much related to the general importance attached to multilateral structures and belief in the effectiveness of international cooperation. ${ }^{3}$ In the case of the ILO, however, this hypothesis has proved not to be completely true, as I will show. And in the light of the recent

I. For a brief introduction to the ILO in the international organizations system, see J. McMahon, "The International Labour Organization", in E. Luard (ed.), The Evolution of International Organizations (London, 1966), pp. 177-199; idem, "International Labour Organization (ILO)", in G. Schiavone, International Organizations: A Dictionary and Directory (Basingstoke, 2005), pp. 193-196; E. Prügl, "International Labor Organization (ILO)”, in M. Griffiths (ed.), Encyclopedia of International Relations and Global Politics (New York [etc.], 2005), pp. 422-425.

2. An earlier version of this article was presented at the conference "The International Labour Organization: Past and Present", Brussels, 5-6 October 2007, a joint initiative of the International Institute of Social History (Amsterdam), the Institute of Social History (AMSAB-ISG, Ghent), Ghent University, and the Free University Brussels.

3. L. Sohn, "The Growth of the Science of International Organizations", in K. Deutsch and S. Hoffmann (eds), The Relevance of International Law: Essays in Honor of Leo Gross (New York, 1971), p. 334. 
globalizing trends in labour history, it is also inevitable to ask the question how "global" past and present research on the ILO has been. After all, the ILO is an international organization aimed at promoting labour rights worldwide and fighting poverty and social inequality, especially in the developing world. Consequently there is a highly interesting research potential for authors interested in labour topics related to the nonWestern world, i.e. Latin America, Africa, and Asia. This essay will show that ILO literature, however, is not as global as it could and should be.

\section{THE SPECIFICITY OF ILO HISTORIOGRAPHY}

Looking at the wide range of available studies on ILO history, there are two essential characteristics. First of all, ILO history is definitely not a field that has been exclusively occupied by historians. International and industrial relations specialists, sociologists, lawyers, and labour economists have also been interested, from different perspectives and posing different research questions, in ILO history. The scope of this review article will therefore be multidisciplinary. I have included all studies that pay attention to the external-environmental and internalorganizational dimensions of the ILO and are therefore relevant for a better understanding of the organization's history.

Secondly, the ILO has been the object of research from two angles. What I call "inside studies" are produced by the International Labour Office, the Secretariat of the International Labour Organization in Geneva, and/or by (former) ILO officials. The organization itself has produced considerable literature about its origins, evolution, functioning, and performance, often for commemorative purposes. Sengenberger and Campbell refer to "the good tradition of the ILO to use important anniversary years for review, reflection and assessment, for looking backwards and forwards". ${ }^{4}$ In their view, 1944 represents the ILO's Silver Jubilee, I969 its Golden Anniversary (when the organization was also awarded the Nobel Peace Prize) and 1994, after seventy-five years, its Diamond Age. In many cases this "self-promotion" has been undertaken by officials, who have been personally involved in one way or another in the work of the ILO. The authors write about the ILO on the basis of their ILO engagement. This does not mean that the works discussed may not be critical, coherent, or scientifically composed, but most of these studies were specially written to expound and justify the ILO's work and self-image.

"Outside studies" have been produced by academics who have an independent scientific position. The publications are not shaped by a personal link to the organization, but by scientific interest, based on 
theoretical questions and frames of reference, and an historical approach that goes beyond the institution and its own sources. This group of authors approach the institution from a more critical perspective. In a few cases, these groups cannot be strictly differentiated. A former official, Robert Cox, for instance, left the organization after a career of twentyfive years and became an eminent Professor of International Relations with a highly critical perspective on the ILO. In what follows, I will take the "inside" as well as the "outside" studies into account since both are essential and substantial to drawing general conclusions on the state of the field.

A reading of the literature reveals roughly five periods of ILO historiography with different characteristics and analytical foci. Based on this analysis of the past trends and the current state of the field, I will conclude this survey article with comments on lacunae and possible paths for future research.

\section{THE FIRST DECADE: “THE CAPRICIOUS AND FANTASTIC PLAY OF CONSTITUTIONAL TEXTS AND SOCIAL REALITIES"'s}

Studies about the ILO and its history are well available from the very beginning. ILO historiography has its origins in the "insider literature" of the I920s. The "first-generation" producers of ILO histories were not professional historians, but often ILO leaders, labour law experts (e.g. Ernest Mahaim ${ }^{6}$ ), or representatives of governments (George Barnes,

5. A. Thomas, "The International Labour Organization: Its Origins, Development and Future", International Labour Review [hereafter ILR], I (I92 I); this article was reprinted in $I L R$, I 35 (1996), pp. 26I-276, 263.

6. Ernest Mahaim (1865-1938), a Law professor of the University of Liège, one of the founding fathers of the International Association of Labour Legislation in 1900 and the ILO in 1919, and the representative of the Belgian government in the ILO Governing Body and the International Labour Conferences in Geneva. See also J. Van Daele, "Engineering Social Peace: Networks, Ideas, and the Founding of the International Labour Organization", International Review of Social History [hereafter IRSH], 50 (2005), pp. 435-466. E.g. E. Mahaim, "Some Legal Questions Relating to International Labour Conventions ", ILR, 20 (1929), pp. 765-796; idem, "Les principes de la législation internationale du travail”, Bulletin de la Classe des Lettres et des Sciences Morales et Politiques, I 3 (1927), pp. 204-233; idem, L'Organisation du travail de la Société des Nations et la Conférence de Washington (Brussels, I920); idem, "International Labour Law", ILR, I (I92I), pp. 283-286 (repr. in "75 Years of the International Labour Review: A Retrospective", ILR, I35 (I996)); idem, "Histoire de la convention de Washington sur la durée de travail”, Revue Economique Internationale, 4 (1928), pp. 513-545.

7. George Nicoll Barnes (1859-1940), former trade-union Secretary, member of the Labour Party, and leader of the British delegation at the Paris Peace Conference in I919; G.N. Barnes, History of the International Labour Office (London, 1926). See also his autobiography: idem, From Workshop to War Cabinet (London, 1923). 
Max Lazard ${ }^{8}$ ) and trade unions (Léon Jouhaux, ${ }^{9}$ Jan Oudegeest $^{10}$ ), who were personally involved in the founding and/or decision-making structures of the organization. ${ }^{\text {II }}$ In the first decades it was also the International Labour Office itself that analysed and published the history of the organization, ${ }^{\mathrm{I} 2}$ for instance in 1929 , on the occasion of the tenth anniversary. ${ }^{\mathrm{I}}$ From the beginning, academics too were interested in the ILO, especially legal scholars and political scientists. They studied the organization as a new phenomenon within the broader framework of international relations and the development of public international law. ${ }^{\mathrm{I}}{ }^{4}$ A remarkable detail is that a considerable proportion of the academic literature was prefaced by (or addressed to) the first director of the ILO, Albert Thomas.

8. Max Lazard (1875-1953), a French sociologist, unemployment expert, and delegate of the French government at the Peace Conference of Versailles; M. Lazard, L'Organisation permanente du travail (Paris, 1922).

9. Léon Jouhaux (1879-1954), leader of the French Confédération Générale du Travail (CGT), member of the Commission on International Labour Legislation in 1919 and workers' representative in the ILO Governing Body and International Labour Conferences; L. Jouhaux, L'Organisation internationale du Travail (Paris, I92 I).

Io. J. Oudegeest, “The International Trade Union Movement and the Labour Office”, ILR, I (I92I), pp. 4I-44. In this article the Dutch trade-union leader and representative to the International Labour Conferences Jan Oudegeest (1870-1950) reviewed the role of the international trade union movement in, and independent of, the ILO.

I I. E.g. E.J. Solano (ed.), Labour as an International Problem (London, I920) is a collection of essays by ILO founding fathers, George Barnes, Emile Vandervelde, Harold Butler, Sophy Sanger, Arthur Fontaine, Minoru Oka, James Shotwell, etc.

I2. L'Organisation internationale $d u$ Travail et la première année de son activité (Geneva, I92 I); The International Labour Office as a World Centre of Information (Geneva, 1927).

13. The First Decade of the International Labour Organization (Geneva, 1930); The International Labour Organization 1919-I929 (Geneva, 1930); J. Delbecq, Dix ans du BIT à vol d'oisean (Annemasse, I930).

I4. J. Godart, Les clauses du travail dans le Traité de Versailles (Paris, 1920); M. Guerreau, $L$ 'Organisation internationale $d u$ Travail. Une nouvelle institution $d u$ droit des gens (Paris, 1923); P. Devinat, L'Organisation internationale du Travail (Paris, I923); J. Chateau, De la compétence de l'Organisation internationale du Travail en matière de travail agricole (Paris, 1924); R. Tremelloni, L'Organizzazione internationale de lavoro (Milan, I924); A. Vabre, Le droit international du travail (Paris, I925); A. Chisholm, Labour's Magna Charta: A Critical Study of the Labour Clauses of the Peace Treaty and of the Draft Conventions and Recommendations of the Washington International Labour Conference (London, 1925); M. Drechsel, Le traité de Versailles et le méchanisme, des conventions internationales du travail (Brussels, 1926); P. Périgord, The ILO: A Study of Labor and Capital in Cooperation (New York, 1926); $\mathrm{H}$. Van Zanten, L'influence de la Partie XIII du traité de Versailles sur le développement du droit international public et sur le droit interne des états (Leiden, 1927); L. Wolscht, Die internationale Regelung des Arbeitsrechts auf Grund des Versailler Friedensvertrages unter besonderer Berücksichtigung der seitherigen Entwicklung (Wolfenbüttel, 1927); E. Hiltonen, La compétence de l'Organisation internationale du Travail. I. Compétence de fond (Paris, I929); G. Scelle, L'Organisation internationale du Travail et le BIT (Paris, 1930); C. Argentier, Résultats acquis par l'Organisation permanente du travail de 1919 à 1929 (Paris, 1930). 
During the first years this "outsider" literature remains close to the insiders' perspective: a very descriptive history with a formal institutional focus on the general aspects of the organization. The frame of reference is the constitutional mandate and the actual operation of the organization with its methods and means to approach international labour legislation, often in close relation to the role of the member-states. ${ }^{\text {Is }}$ Consequently, these early writings on ILO history are rather oldfashioned from a methodological point of view. They contain in many cases a table of ratifications of conventions and the full text of Part XIII of the Paris Peace Treaty, the constitutional text of the ILO, in an appendix. A significant fact is that these first publications largely pay attention to the ideological and institutional roots of the organization during the nineteenth century as a way of emphasizing its "long" history. ${ }^{16}$

It is not coincidental that the tone of all those publications is very optimistic. Authors in the first phase shared a strong belief in the success of the ILO as part of a new multilateral system hosted in Geneva, a city of flourishing international intellectual and operational activities. They tried to explain how a peaceful world could be created and what contribution the ILO could (or should) make towards that. G.A. Johnston, an ILO official, had already written in 1924 that:

$[\ldots]$ the passage of time has brought a gradually deepening conviction that this Organization, founded in a spirit of generous enthusiasm, is destined, amid all the sombre difficulties of the post-war world, to fulfil a function of gradually increasing importance in the maintenance of that international peace which is based on social justice. ${ }^{17}$

After all, the ILO was a new institution that had to prove itself and the purpose of this first phase in ILO historiography was mainly to explain what the institution was doing and how it came into being.

I 5. See e.g. H. Fehlinger, "Deutschland und die Internationale Arbeitsorganization", Zeitschrift für Volkerrecht, I4 (1927), pp. 23-29; H. Crommelin Van Wickevoort, Wereldwetgevers. De Internationale Arbeidsorganisatie aan bet werk (The Hague, I93I); J. Puchades Monton, Organizacion internacional del trabajo de la sociedad de las naciones (Valencia, I93I).

I6. E.g. A. de Maday, Charte internationale du travail (Paris, I92 I); F. Podmore, Robert Owen: A Biography (London, 1923); A. Thomas, "Quelques notes sur Robert Owen et la législation internationale du travail”, in Mélanges offerts à Charles Andler (Strasbourg, 1924), pp. 323-333; R. Weiss, Un précurseur de la législation internationale du travail, Daniel Legrand (I783-I859), son oewvre sociale et internationale (Paris, 1926); A. Millerand, "Origines françaises du BIT", Revue des Deux Mondes, I02 (1932), pp. 589-60I; A. de Maday, "Necker, précurseur du pacifisme et de la protection ouvrière", Revue de l'Institut de Sociologie Solvay, is (i935), pp. 39-52.

17. G.A. Johnston, International Social Progress: The Work of the International Labour Organization of the League of Nations (London, 1924), p. 5. 
Not surprisingly the literature remained still very Europe-centred, as the ILO was itself. Although several important Asian and Latin American countries had already joined the organization in the early years (such as India, China, Japan, Argentina, Brazil, and Chile), the ILO still remained largely dominated by "a club of like-minded states", ${ }^{18}$ mostly the major industrialized countries within Europe that - despite early protests from non-European members - occupied the crucial positions in decisionmaking (e.g. in the ILO Governing Body). This Eurocentrism is clearly reflected in the bulk of the early writings. The Latin American countries that were represented in the ILO from the beginning, such as Argentina and Chile, produced some interesting studies with a specific focus on regional problems (for instance, international migration policies). ${ }^{19}$ However, the most significant exception to the early Eurocentrism is India. It is significant that studies on the relations between the ILO and India were published early on. ${ }^{20}$ India, a dominion of the United Kingdom, joined the ILO as one of the very first non-European members and participated actively in the organization. But overall, non-European studies were rare. ${ }^{2 \mathrm{I}}$

All these early works are characterized by a very legitimizing concept of the institutional roots, the structure, the tasks, the raison d'être, and the mission of the organization, as well as the position and the identity of the ILO in the broader international system, in particular in its relationship with the League of Nations. Therefore, historical writing in the I920s can be defined as an instrument of self-justification. An important pioneer in this "scholarship of legitimation" was the first Director of the ILO, the French socialist, Albert Thomas (I878-1932). As a historian himself, Thomas realized that historical knowledge was an important tool for a better understanding of the present, and an essential foundation for the

I8. K.N. Dahl, "The Role of ILO Standards Policy in the Global Integration Process", Journal of Peace Research, 5 (1968), p. $32 \mathrm{I}$.

19. E.g. C. Saavedra Lamas, Tratados internacionales de tipo social (Buenos Aires, I922); La República Argentina en la Organización Internacional del Trabajo (Buenos Aires, 1925); T. Romero Hodges, La Organización Internacional del Trabajo y la Legislación Social de Chile (Santiago, 1930); F. Walker Linares, La sociedad de las Naciones y sus Organismos del Trabajo (Santiago, 1930).

20. India and the International Labour Organization (Geneva, 1924); P.P. Pillai, India and the International Labour Organization (Patna, 193 I); L. Sundaram, India and the ILO (London, 193 I) (repr. from Asiatic Review, 27 October 193 I); L.N. Birla and P.P. Pillai, India and the ILO (Bombay, 1946).

2 I. Other examples: F. Wilson, “The Pacific and the International Labor Organization”, Pacific Affairs, 5:6 (1932), pp. 497-5 I I (on the ILO's contribution to specific problems in the Pacific area, such as native labour and migration); Much more descriptive (rather a detailed description of the participation of the Pacific delegations in the Conference of 1930 than an historical analysis) is E. Green, "The Pacific and the International Labour Conference", Pacific Affairs, 3 (1930), pp. $845-853$. 
ILO's future effectiveness. In one of his earliest articles as Director of the ILO, in the International Labour Review (the flagship journal of the ILO on all aspects of the world of work) in I92 I, Thomas stated that it was a crucial task for the ILO "to make known the need for and utility of the Organization, to arouse in all countries and in all circles the sympathy and faith which it requires. Where are we? What future is open to the ILO? How far will its work be effective?". ${ }^{22}$ That is why ILO historiography was, in the first years, so important for ILO protagonists.

\section{THE CRISIS OF THE 1930 S AND WORLD WAR II: “TOWARDS BETTER THINGS" 23}

In this period, ILO historiography followed more or less the pattern of the previous decade, but against a different international background. During the turbulent time of the I930s serious criticisms of the international system were heard. The worldwide economic crisis, mass unemployzment, and the rise of dictatorship in Europe and Latin America could not be remedied or halted by the League of Nations and the ILO. In a context of economic and political nationalism European member-states also ratified significantly less ILO conventions. The ILO and individual ILO officials responded by some écritures de defense, explaining what the organization was meant for and why and how it should continue working. ${ }^{24} \mathrm{~A}$ combination of legitimacy and defence can also be found in the first books on the ILO Director Albert Thomas. His unexpected death in 1932, when he was still actively in charge, gave rise to the first influx of biographical literature on his life and ideas, produced by the $\mathrm{ILO}^{25}$ as well as by outsiders. ${ }^{26}$

While legal and political science scholars continued writing on general aspects of the organization, ${ }^{27}$ there was growing attention in the literature

22. Thomas, "International Labour Organization", p. 5.

23. N. Hewett, Towards Better Things: The Story of the International Labour Organization (London, I936).

24. E.g. H. Butler, "The Past, Present and Future of the ILO", in Geneva Institute of International Relations, Problems of Peace (London, I931), pp. 29-43; La Organización Internacional del Trabajo. 'Laboratorio de Paz Social' (Ginebra, 1934); L'Organization internationale du Travail. Ce qu'elle est, ce qu'elle a fait (Geneva, I936); E. Phelan, "The ILO and the Future of the Collective System", in Geneva Institute of International Relations, Problems of Peace (London, I937), pp. I27-I 44.

25. E. Mahaim e.a., Albert Thomas, I878-1932 (Annemasse, 1932); E.J. Phelan, Yes and Albert Thomas (London, 1936). Also translated in French as Albert Thomas et la creation $d u$ BIT (Paris, 1936).

26. E. Poisson, Le coopérateur Albert Thomas. Un quart de siècle de vie militante (Paris, 1933).

27. A.S. Cheyney, The International Labor Organization (Philadelphia, PA, 1933); A. Berenstein, Les organisations ouvrières. Leurs compétences et leur rôle dans la Société des Nations (Brussels, 1936); J. Zarras, Le controle de l'application des conventions internationales du travail 
towards the economic role of the ILO. It was no coincidence that the debate on the efforts of the ILO to play a more active part in shaping economic conditions took off during the crisis of the I930s. In the first years the ILO had dealt with the social effects rather than with the causes of existing economic conditions. During the Great Depression, when it faced the challenge of excessive unemployment due to cyclical crises in capitalism, the ILO started advocating measures of monetary and credit policy, international trade, and public works, all with the purpose of stimulating economic recovery. ${ }^{28}$

It was also no coincidence that just before and in the immediate aftermath of the long-expected entry of the United States into the ILO in I 934 the literature on the relations between Geneva and Washington grew. In the international polemic on ILO membership different arguments were highlighted. On the one hand, there were the American opponents, who often used the critique that the ILO was "a League of Nations instrument" as it was financially dependent on the League, which the Americans would never join. ${ }^{29}$ For the American Federation of Labour (AFL), the ILO, with its double government representation, was nothing more than "a state machine". ${ }^{30}$ Traditionally rooted in a very pragmatic and voluntarist ethos, the AFL favoured not laws but privately negotiated contractual agreements between unions and employers without any government interference. On the other hand, the advocates of the ILO defended the decision of President Roosevelt and his labour administration to join the ILO. In the context of the New Deal social reforms it was generally thought that the ILO would be a useful instrument for the US. ${ }^{3 \text { I }}$

(Paris, 1937); F. Wilson, Labor in the League System: A Study of the International Labor Organization in Relation to International Administration (Stanford, CA, 1937); A.N. Molenaar, De naleving van arbeidsconventies. Rede aan de Rijksuniversiteit te Leiden op II februari 1938 ('s Gravenhage, 1938).

28. L. Chaudouard, Le rôle de l'Organisation internationale du Travail dans l'activité économique (Paris, 1933); L.E. Lorwin, "The ILO and World Economic Policy", ILR, 33 (1936), pp. 457-467; C.W. Jenks, "L'Organisation internationale du Travail face au problème de l'organisation de l'économie", Annales de l'économie collective, 29 (I937), pp. I I I-247.

29. The ILO received the contributions of its member-states through the Fourth Committee of the League of Nations General Assembly; P.G. Steinbicker, "Is the International Labor Organization Really Autonomous?”, American Political Science Review, 29 (1935), pp. 866-870. 30. M. Woll, "The International Labour Office: A Criticism", Current History, 3 I (1930), pp. 683-689. Matthew Woll was vice-president of the AFL.

3. S. Miller, What the International Labor Organization Means to America (foreword by John G. Winant) (New York, 1936); E. Phelan, “The United States and the ILO”, Political Science Quarterly, 50 (1935), pp. I07-I2 I; E.J. Phelan, M.O. Hudson and J.T. Shotwell, "The International Labour Organization: Membership of the United States and its Possibilities", International Conciliation, 309 (1935), pp. 105-I5 I; B.E. Lowe, International Protection of Labor: International Labor Organization, History and Law (New York, 1935); W.L. Tayler, Federal States and Labor Treaties: Relations of Federal States to the International Labor 
An important protagonist in the American campaign for ILO membership was James Shotwell, a Professor of History at Columbia University and an eminent promoter of international cooperation. ${ }^{32}$ Shotwell had attended the Versailles Peace Conference in I9I9 as a member of the American delegation and later chaired the American Committee on International Intellectual Cooperation of the League of Nations. In 1934 he published his two major volumes on the origins of the ILO with the explicit motive of pushing the US government to join the organization. ${ }^{33}$ Rather than an in-depth historical analysis, Shotwell's volumes provide valuable source materials as they bring together an important collection of chapters written by ILO people involved in the founding process, accompanied by a rich and detailed collection of archives documents and texts (e.g. the original minutes of the Commission on International Labour Legislation that prepared the foundation of the ILO in I919) that are useful for historians interested in the origins and early years of the ILO. One consequence of this upsurge in the literature on the new American membership was that from the I930s onwards ILO historiography became gradually less Europe-centred.

World War II was a period of deep transition for the ILO. ${ }^{34}$ Like the League of Nations, its existence was put into question, but the ILO managed to survive the war and find a place within the new multilateral system as a specialized agency of the United Nations. This period of reorientation of its role and position, programmatic rethinking, and

Organization (with a foreword by Samuel McCune Lindsay) (New York, 1935); M. Hudson, "The Membership of the United States in the ILO", American Journal of International Law, 28 (1934), pp. 669-684; "The International Labor Organization", special issue Annals of the American Academy of Political and Social Sciences, I66 (1933); U. Hubbard, "The Cooperation of the United States with the League of Nations and the ILO", International Conciliation, 274 (193I), pp. 675-825.

32. On Shotwell, see H. Josephson, James T. Shotwell and the Rise of Internationalism in America (Rutherford, NJ [etc.], I975); C. Debenedetti, "James T. Shotwell and the Science of International Politics", Political Science Quarterly, 89 (1974), pp. 379-395; idem, "Peace was his Profession", in F. Merli (ed.), Makers of American Diplomacy: From Benjamin Franklin to Henry Kissinger (New York, 1974), pp. 385-406.

33. "Justified by its history, freed from entanglements with the Peace Treaties, safeguarded by its Constitution from any tendencies to interfere with domestic legislation, the ILO offers countries like the United States an instrument which can be used greatly to its advantage and which in no conceivable way can be used against it. [...] It would be a happy although not calculated consequence of this documentary history if it should lessen the blindness of prejudice which has hitherto deprived the US of an avenue of helpful international cooperation in the field that bears the marks of the worst ravages of the industrial depression, that which has to do with the conditions of daily life of the common man"; J.T. Shotwell, The Origins of the International Labour Organization (New York, 1934), 2 vols, pp. xxix-xxx.

34. On the eve of World War II the ILO had made concrete plans to publish an overview volume, looking back at its first twenty years. Due to the outbreak of the war, the volume remained unpublished. (With thanks to Remo Becci, ILO archivist, for this information.) 
adaptation to the postwar international system led to a revival in the literature, focusing explicitly on the ILO's intention to preserve its independence and uniqueness. Looking back on the past decades, taking stock of the challenges by positioning itself at the side of the United States and Great Britain, the leading powers of that time, and looking forward to its future under the new umbrella of the UN is the main characteristic of all these publications. The analyses of both "insiders" 35 and "outsiders" 36 were still mainly institutional, focusing on the general, legal, and political consequences of the international problems of war and peace.

\section{THE FIRST DECADES OF THE COLD WAR (LATE 1940 S-MID 1970 S): PROFESSIONALIZATION AND DIVERSIFICATION}

From an academic point of view, ILO historiography becomes more interesting and diversified from the I950s onwards. This is remarkable. While the Cold War polarized and more or less paralysed international relations, and international organizations lost a large part of their independence, one would expect that this would lead to diminishing research interest of scholars in international organizations. But this is certainly not the case for the ILO.

35. C.W. Jenks, "The Contribution of the ILO to the Development of Procedures of Peaceful Change", World Affairs, 4 (1939), pp. 36I-379; J. Winant, "Twenty Years of the ILO (1919-1939)", Annals of Collective Economy, (1939), pp. 61 I-625; J. Godart, The Future of the ILO (Montreal, I943); C. Goodrich, "The International Labor Organization", in Pioneers in World Order (New York, I944), pp. 87-106; C. Riegelman, "Labor's Bridgehead: the ILO", Political Science Quarterly, 60 (1945), pp. 205-22 I; C.W. Jenks, "Revision of the Constitution of the International Labour Organization", BYIL, 23 (1946), pp. 303-3 I7; E.J. Phelan, The ILO and the United Nations/L'OIT et les Nations Unies (Montreal, 1946); idem, “The Contribution of the ILO to Peace", ILR, 59 (1949), pp. 607-632.

36. S. Trocmé, L'Organisation internationale du Travail et la guerre (Aix-en-Provence, I942); K. Pribram, "The ILO: Present Functions and Future Tasks", Foreign Affairs, 21 (1942), pp. I 58-167; C. Dechamp, "L'avenir de l'Organisation Internationale du Travail et ses possibilités d'évolution", Revue syndicale suisse, 34 (1942), pp. 345-362; M. Starr, "Labor Issues at San Francisco", Current History, 8 (1945), pp. 517-52 I; J. Price, "The International Labour Organization", International Affairs, 2 I (1945), pp. 30-39; G. Brand, "International Labor Organization in Transition", World Affairs, I 2 (1946), pp. 8 I-89; G. Fischer, Les rapports entre l'Organisation internationale du Travail et la Cour Permanente de Justice Internationale. Contribution à l'étude du problème de la séparation des pouvoirs dans le domaine international (Berne, I946); E.S. Hediger, "The International Labor Organization and the United Nations", Foreign Policy Reports (New York), 22:6 (1946), pp. 7I-79; R.J.P. Mortished, World Parliament of Labour: A Study of the ILO, its Past Achievements and Potentialities for the Future, and Proposals for its Reorganization (London, 1946); J. Fried, "Relations between the UN and the ILO", American Political Science Review, 4I (1947), pp. 963-977; J. Sulkowski, "The Competence of the International Labor Organization under the United Nations System", American Journal of International Law, 45 (195I), pp. 286-3I3. 
On the one hand the stream of "self-promotion" continued, that is to say, the ILO's literature of "self-identity" in the context of the organization's tradition of contributing to its own image, albeit in the new context of postwar international relations. Former ILO officials published memoirs and autobiographies in which they shed light on personal experiences and turning points, such as the war. ${ }^{37}$ How the ILO "turned the corner" after World War II was a popular topic, ${ }^{38}$ as was the evolution of internal structures, e.g. on the occasion of the rooth session of the Governing Body in 1946. ${ }^{39}$ A good deal of "inside" publication on the ILO history was brought out on the occasion of anniversaries, again ideal moments for reflection on past, present, and future achievements. In 1949 the ILO celebrated its thirty years of existence, but it was not long after the war and the move from Montreal back to Geneva was only three years earlier, so the festivities were kept quite small with a few booklets and articles in the International Labour Review. ${ }^{40}$ In 1959 mainly outsiders published an ILO history. ${ }^{4 \mathrm{I}}$

The organization's 5oth anniversary ten years later in 1969, when the ILO received the Nobel Peace Prize, led to a veritable "explosion" of historical reviews, ${ }^{42}$ to which former high-level ILO officials and Directors-General not surprisingly made a significant contribution. ${ }^{43}$ It is

37. J.G. Winant, Letter from Grosvenor Square: An Account of a Stewardship (London, 1947); H. Butler, The Lost Peace: A Personal Impression (London, 1950); H. Butler, Confident Morning (London, I950).

38. "The International Labour Organization Since the War", $I L R, 67$ (1953), pp. I09-I55; E. Phelan, "Some Reminiscences of the ILO", Studies: An Irish Critical Quarterly, 44 (1954), I7I, pp. 24I-270; idem, "The ILO Sets Up its Wartime Center in Canada", Studies, 44 (1955), I74, pp. I 52-170; idem, "The ILO Turns the Corner", Studies, 45 (1956), 178, pp. I60-186; idem, "After Pearl Harbour: ILO Problems", Studies, 45 (1957), I 82, pp. 193-206.

39. "One Hundred Sessions of the Governing Body of the International Labour Office", ILR, 55 (1947), pp. 20I-226; "The Composition of the Governing Body of the International Labour Office”, ILR, 70 (1954), pp. 496-525.

40. E.g. 30 Years of Struggle for Social Justice (Geneva, I949); "The Thirtieth Anniversary of the Foundation of the ILO: I919-1949", ILR, 60 (1949), pp. 559-571.

4I. G. de Lusignan, L'Organisation internationale du Travail (1919-1959) (préface de Jean Morellet) (Paris, 1959); M. Montceau, L'Organisation internationale du Travail (1919-1959) (Paris, 1959).

42. J. Price, ILO: so Years On (London, I969); “Cinquantenaire de l'OIT, I919-1969", Revue française des Affaires sociales, 23 (1969), pp. I-226; G. Lefranc, "L'Organisation internationale du Travail à 50 ans”, Revue de Défense Nationale, 25 (1969), pp. 1764-1776; J.A. Tijerino-Medrano, "ILO: Fifty Years of Labor", Américas, 2 I:7 (1969), pp. 16-22; I. Maxim, "L'Organisation internationale du Travail à son demi-centenaire”, Revue Roumaine d'Etudes Internationales, 2:6 (1969), pp. I04-I I 2; J. Collins, "Fifty Years of the International Labour Organization", Pakistan Horizon, 23 (1970), pp. 5 I-6I.

43. D. Morse, The Origin and Evolution of the ILO and its Role in the World Community (Ithaca, NY, 1969); C.W. Jenks, Social Justice in the Law of Nations: The ILO Impact after Fifty Years (New York, I970); idem, Universality and Ideology in the ILO (address at the Graduate 
also no coincidence that several books and articles on the relations between the ILO and its member-states were published on this occasion, quite often by the government departments (social affairs, labour administration, foreign affairs) directly involved in the ILO. ${ }^{44}$ However, the very classical institutional history was still the predominant format, as in the publications of G.A. Johnston, ${ }^{45}$ former Assistant DirectorGeneral, and Anthony Alcock, ${ }^{46}$ an external researcher employed by the ILO for a history book project on the occasion of fifty years of the ILO. While Johnston is very descriptive and sticks to the official account of the organizational development and a summing-up of the major working fields, Alcock was the first to write a comprehensive study of ILO history from its origins until 1970. Despite its shortcomings (this is in the first place a chronological review and lacks, on a certain level, analytical scope), Alcock is still a valuable source of information, simply because he places the ILO and its different actors in a broader historical and international context, from the early decades to the problems of the Cold War.

On the other hand, ILO historiography after World War II went beyond the traditional institutional story. The second half of the twentieth century was characterized by a significant trend towards a more academic historiography, with a diversification in scope, research questions, and subjects. In comparison to the interwar period, studies on the ILO from the I950s became less descriptive, but more critical and analytical. The I950s, and especially the I960s, can be regarded as the real take-off of indepth scientific research on ILO history. There are two significant trends.

Firstly, there is a trend towards professionalization in historical research on the ILO. Professional historians discovered the ILO as a field of study that was, until then, almost exclusively occupied by legal scholars and political scientists specialized in international relations. This was a consequence of the changes in the field of labour history, that in itself became integrated into professional historiography after World War II. ${ }^{47}$

Institute of International Studies, Geneva, 27 October 1969); idem, 1919-1969: 50 Years in the Service of Social Progress (Geneva, I969); N. Valticos, "Fifty Years of Standard-Setting Activities by the International Labour Organization", ILR, I00 (I969), pp. 20I-237; J. Rens, L'histoire de so années (Geneva, 1969).

44. E.g. N. Valticos, "The International Labour Organization and National Parliaments", Interparliamentary Bulletin (Geneva), I969, pp. 16-31; M. Stewart, Britain and the ILO: The Story of Fifty Years (London, I969); N.K. Kakkar, India and the ILO: The Story of Fifty Years (Delhi, 1970); Portugal e a Organizacao internacional do trabalho (Lisbon, 1970).

45. G.A. Johnston, The International Labour Organization: Its Work for Social and Economic Progress (London, 1970).

46. A. Alcock, History of the International Labour Organization (London, 1971).

47. M. van der Linden and L. Heerma van Voss, "Introduction", in L. Heerma van Voss and M. van der Linden (eds), Class and Other Identities: Gender, Religion and Ethnicity in the Writing of European Labour History (New York [etc.], 2002), pp. I I-I 2. 
A typical example of this historical professionalization is the biography of Albert Thomas by Bertus Schaper in $1953,{ }^{48}$ as a doctoral dissertation from the History Department of the University of Leiden, one of the first scientific and independent studies on the ILO's first Director and therefore different from the ongoing stream of official and more hagiographic studies on Thomas. ${ }^{49}$ This kind of professionalization not only implied the production of historical biographies (on e.g. ILO pioneers and Directors-General ${ }^{5 \circ}$ ), but also more attention for the ILO's constituents from a critical-historical perspective, ${ }^{5 \mathrm{I}}$ and a reconsideration of the origins and early decades by academic researchers. ${ }^{52}$

Secondly, research shifted from the general institutional aspects of the ILO as a whole to the analysis of actual decision-making processes within the organization. This trend was clearly influenced by new research within the field of international relations theory. There, the study of the formal arrangements of international organizations (constitutional texts, organization structures, etc.) was gradually abandoned for the analysis of patterns of influence shaping organizational outcomes. ${ }^{53}$ Scholars opened up the "black box" of the ILO and focused explicitly on particular problems and issues such as leadership and the role of the ILO Director-General, ${ }^{54}$ the international supervision of international labour

48. B.W. Schaper, Albert Thomas. Dertig jaar sociaal reformisme (Leiden, 1953) [trans. in French as Albert Thomas. Trente ans de réformisme social (Paris [etc.], 1959)].

49. A. Thomas, International Social Policy (Geneva, I948), composed of passages of Thomas's speeches, reports, and articles; by the French ILO official and Thomas's personal friend, Marius Viple, Albert Thomas vivant. Un grand citoyen du monde (Genève, 1957).

50. E.g. A.M. Allen, Sophy Sanger: A Pioneer in Internationalism (Glasgow, 1958); A. Knepper, John Gilbert Winant and International Social Justice (unpublished doctoral dissertation, New York University, 1963); B. Bellush, He Walked Alone: A Biography of John Gilbert Winant (The Hague, 1968); B. Georges and D. Tintant, Léon Joubaux. Cinquante ans de syndicalisme (Paris, I962); B. Georges, D. Tintant, and M.-A. Renauld, Léon Joubaux dans le mouvement syndical français (Paris, 1979).

5. B. Béguin, The ILO and the Tripartite System (New York, 1959); A. Salah-Bey, L'Organisation internationale du Travail et le syndicalisme mondial (1945-1960) (Ambilly [etc.], 1963); J.P. Windmuller, "Soviet Employers in the ILO: the Experience of the I930s", IRSH, 6 (I96I), pp. 353-374.

52. E.g. J.W. Follows, Antecedents of the International Labour Organization (Oxford, I95 I); P.D. Moynihan, "The United States and the International Labor Organization I889-1934" (unpublished doctoral dissertation, Fletcher School of Law and Diplomacy, I960); idem, "The Washington Conference of the International Labor Organization", Labor History, 3 (1962), pp. 307-334; V. Coussirat-Coustère, Les origines et la naissance de l'Organisation internationale du Travail (Paris, 1970).

53. F. Kratochwil and J. Ruggie, "International Organization: A State of the Art on an Art of the State", International Organization, 40 (1986), p. 755.

54. J.S. Gillespie, The Role of the Director in the Development of the International Labour Organization (New York, 1956). 
standards, ${ }^{55}$ the formation and functioning of the group system, ${ }^{56}$ and bureaucratic policies. ${ }^{57}$ Particularly relevant in this period were two studies on ILO decision-making by Ernst Haas and Robert Cox.

In Beyond the Nation-State Ernst Haas applied a neo-functionalist organization theory to the functioning and outcomes of the ILO. Neofunctionalists assigned a major role to international organizations and the role of international technocrats, not simply as passive recipients of new tasks and authority but as active agents of task expansion. They were given this role as a consequence of the failure of national states to solve substantive problems "beyond the nation-state". With an historical overview since I9I9, Haas shows the ILO as a species of institutionalized interest politics resulting from an interaction of organizational dynamics and typical actor concerns. ${ }^{58}$

A few years later, in 1973, Robert Cox also explained the ILO's evolution by changes in its environment, notably world politics setting the framework for (non-)action. Cox applied a "taxonomical" approach by analysing the ILO as a political system, divided into sub-systems, and developing a framework of analysis by using four variables: environment, actors, patterns of influence, and structure. Subscribing to the realist school in international relations, Cox believed that the interests of the main political powers in world politics were the most crucial determinants of the ILO's autonomy. He concluded that the ILO was a "limited monarchy", identifying the ILO as an organization of "low politics" (in contrast to "high politics" organizations such as the IMF and GATT), but with considerable autonomy from the member-states and a strong leadership. ${ }^{59}$

What Haas and Cox have in common is that they cut the ILO open and dissected its anatomy in order to unravel decision-making patterns and, ultimately, to determine institutional autonomy. Although their theoretical frameworks can be criticized substantially - because of positivist

55. E.A. Landy, The Effectiveness of International Supervision: Thirty Years of ILO Experience (London [etc.], I 966); idem, "The Effectiveness of International Labour Standards: Possibilities and Performance", ILR, I0I (1970), pp. 555-604.

56. T. Landelius, Workers, Employers and Governments: A Comparative Study of Delegations and Groups at the International Labour Conference, 1919-1964 (Stockholm, 1965); A. Suviranta, The Role of the Member State in the Unification Work of the International Labour Organization (Helsinki, I966).

57. N.F. Dufty, "Organizational Growth and Goal Structure: The Case of the ILO", International Organization, 26 (1972), pp. 479-498.

58. E. Haas, Beyond the Nation-State: Functionalism and International Organization (Stanford, CA, 1964).

59. R. Cox, "ILO: Limited Monarchy", in R. Cox, H. Jacobson, and G. Curzon (eds), The Anatomy of Influence: Decision Making in International Organization (New Haven, CT [etc.], 1973), pp. 102-138. 
determinism - these studies are still very valuable for their massive empirical research. A remarkable detail is that the studies of both Haas and Cox have been completely overlooked by the ILO itself. The International Labour Review, for instance, has never devoted a single book review to one of these academic studies. In Cox's case, this is not surprising, since he left the ILO, as the Director of the International Institute for Labour Studies, after a dispute with the organization and the then Director-General, Wilfred Jenks, on the autonomy of the Institute and its publications.

Overall, all these new directions in ILO research were evoked by the observation of increasing discrepancies between the original constitutional designs and daily organizational practices, in a context of political tensions during the Cold War. This was also the general environment that led to a growing research interest in the power and prestige of individual states within international organizations. It will come as no surprise that, against the background of the Cold War, the United States ${ }^{60}$ and the USSR $^{6 \mathrm{I}}$ especially were popular research topics. Although these were definitely not the member-states that scored highly in terms of compliance in national legislation with international labour standards, the peculiar relationships between Washington and Moscow as well as with international organizations such as the ILO were interesting cases for historical analysis. The multitude of this kind of literature explains the still predominantly North-Atlantic bias in this period.

The slowly growing scholarly attention towards the non-Western world could not overcome this. A wave of decolonization that led to a massive increase in ILO membership during the I950s and I960s put new issues on the ILO's political agenda and consequently also on the agenda of ILO researchers. A new line of research began concentrating on the impact on ILO work of developing countries' membership with regard to tripartism, decision-making organs, and the orientation and content of the

60. R. Hislop, The United States and the Soviet Union in the ILO (Ann Arbor, MI, I96I); Moynihan, "The United States and the ILO"; J. Tipton, Participation of the United States in the ILO (University of Illinois, Institute of Labor and Industrial Relations, I959); J. Johnson e.a., "The US and the ILO", Annals of the American Academy of Political and Social Sciences, 3 10 (1957), pp. I82-195; A. French, A Problem of International Cooperation: A Study of the Evolution of the ILO with Particular Reference to US Participation (Yale University, 1954).

6r. C. Osakwe, The Participation of the Soviet Union in Universal International Organizations: A Political and Legal Analysis of Soviet Strategies and Aspirations inside the ILO, UNESCO and WHO (Leiden, I972); M. Downs, Study of Soviet Participation in the ILO with Emphasis on the Period 1960-I964 (Notre Dame University, IN, 1971); Hislop, United States and the Soviet Union in the ILO; H. Jacobson, "The USSR and the ILO", International Organization, I4 (1960), pp. 402-428; K. Tidmarsh, The Soviet Union and the ILO (Oxford, 1957). 
ILO's work. Against the background of a growing North-South divide, parallel to the traditional East-West conflict in the heyday of the Cold War, there was a growing interest in the role of the ILO in the broad multilateral effort to establish universal human rights. The focus was, of course, on rights at work, including the formulation of several major standards (on freedom of association, social security, and nondiscrimination). ${ }^{62}$ At the core of the debate was the supposed dichotomy between universalism and diversity, or the problems of reconciling a wide international membership with the specific needs for the regions (Latin America, Asia, and Africa). ${ }^{63}$ An important protagonist of this strand in the literature was Wilfred Jenks. As a leading official and the DirectorGeneral of the ILO between 1970 and 1973 he was directly concerned with these problems. ${ }^{64}$

Within this cluster of literature, the issue of technical cooperation received specific attention. This third pillar of the main activities of the ILO, which was developed after World War II in parallel with standardsetting and international expertise, was conceived as an instrument of development aid. ${ }^{65}$ But in comparison to the standard-setting tasks and legal procedures of the ILO, technical cooperation was seriously underresearched in this period. The purely legal literature still set the tone. ${ }^{66}$ The International Labour Review, for instance, published a series of articles on the compliance of national legislation in the member-states with international labour standards. ${ }^{67}$

62. E.g. W.P. Gormley, "The Emerging Protection of Human Rights by the International Labour Organization", Albany Law Review, 30 (1966), pp. I3-51; E. Haas, Human Rights and International Action: The Case of Freedom of Association (Stanford, CA, 1970).

63. J. Monat, L'Organisation internationale du Travail et le régionalisme (unpublished doctoral dissertation, University of Lyon, I955); P.F. Gonidec, "L'OIT et l'Afrique Noire. Universalisme et régionalisme”, Recueil Penant, 70 (1960), 679, pp. 273-290.

64. C.W. Jenks, Human Rights and International Labour Standards (London [etc.], 1960); idem, Human Rights, Social Justice and Peace: The Broader Significance of the ILO Experience (Symposium on the International Protection of Human Rights, Norwegian Nobel Institute, I967); idem, "Universality and Ideology in the ILO", Annals of International Studies, I (1970), pp. $45-64$.

65. J. Chapelle, La collaboration de l'Organisation internationale du Travail et des Nations Unies en matière d'assistance technique (unpublished master's thesis, Liège University, 1956); J. Rens, "The ILO and International Technical Cooperation", ILR, 83 (I96I), pp. 4I3-435; N.F. Dufty, "Technical Assistance and the ILO”, Journal of Industrial Relations, 9 (1967), pp. 245-257; J. Rens, Le programme andin. Contribution de l'OIT a un projet-pilote de coopération technique multilatérale (Brussels, 1987).

66. L.-E. Troclet, Législation sociale internationale (préface de Georges Scelle) (Brussels, I952); E. Vogel-Polsky, Du tripartisme à l'Organisation internationale du Travail (Brussels, 1966); Dahl, "Role of ILO Standards", pp. 309-35 I; N. Valticos, Droit international du travail (Paris, 1970).

67. These are only a few examples to illustrate the format (for more case studies per country, see the ILR): G.A. Johnston, "The Influence of International Labour Standards on Legislation 


\section{FROM THE MID $1970 \mathrm{~S}$ UNTIL THE END OF THE COLD WAR: POLITICIZATION AND STAGNATION}

The I970s were a decade of strong politicization and weakened autonomy of the ILO as a consequence of the deepening polarization during the Cold War in combination with quick changes in Directors-General. In I977 the US withdrew from the ILO for a number of interconnected reasons, denouncing the "erosion of tripartism" and the selective concern of the ILO for human rights. The immediate cause was the condemnation of Israel on the grounds of racial discrimination and violation of tradeunion rights in the occupied territories and the admission of the Palestine Liberation Organization (PLO) as an observer at the International Labour Conference. The ILO suffered after the US withdrawal as it saw its budget severely reduced.

In the I980s the Keynesian model was replaced by the so-called neo-liberal "Washington consensus": instruments of social dialogue were questioned and social security and welfare expenditures were cut in a phase of liberalization and deregulation of the dominating global economy. In this context the ILO lost ground. It could not play a very active role because of the political divisions among its members. Not only the East-West division, but also the North-South conflict paralysed the ILO. This is clearly reflected in the state of historical research, characterized by a general disinterest in the organization's role in world society. Some reference works were published, but they were generally characterized by a "return" to the institutional format of the earlier days. ${ }^{68}$

Robert Cox's Labor and Hegemony, published in 1977, the year the US withdrew from the ILO, was much more analytical and critical. Cox had left the realist school in international relations by then and shifted to a neo-Gramscian approach. He participated in the so-called "American hegemony debate" by explaining international organizations in terms of hegemonic power relations. As such, Cox defined the ILO as an

and Practice in the United Kingdom", ILR, 97 (1968), pp. 465-487; V. Ayissi Mvodo and R. Le Faou, "The Influence of International Labour Standards on the Legislation of Cameroon", ILR, I08 (1973), pp. I63-185.

68. V.-Y. Ghebali, Organisation internationale et guerre mondiale: le cas de la Société des Nations et de l'Organisation internationale du Travail pendant la seconde guerre mondiale (unpublished doctoral dissertation, University of Grenoble, 1975); M. Tortora, Institution spécialisée et organisation mondiale: étude des relations de l'OIT avec la SDN et l'ONU (Brussels, I980); A.K. Tikriti, Tripartism and the International Labour Organization: A Study of the Legal Concept, its Origins, Function and Evolution in the Law of Nations (Stockholm, 1982); E. Osieke, Constitutional Law and Practice in the International Labour Organization (Dordrecht [etc.], 1985); V.-Y. Ghebali, The International Labour Organization: A Case Study on the Evolution of UN Specialised Agencies (Dordrecht, 1989). 
international vehicle through which global power in production relations could be enhanced. ${ }^{69}$

Self-evidently the US withdrawal in 1977 and its re-entry in 198 I gave rise to a remarkable flood of literature. ${ }^{70}$ At the same time, there was also a renewed attention towards the American participation in the ILO in earlier decades. $^{71}$ Relations with other member-states were a classic topic for research, fairly descriptive and along the lines of traditional institutional history. ${ }^{72}$ On the side of non-governmental actors, women and employers began to be explored as separate subjects of analysis. For instance, the ILO convention of I95I on equal pay for men and women was at stake in the ever ongoing debate on the special protection and equal treatment of women by the ILO. ${ }^{73}$ There was less debate on the role of employers in the ILO that has been poorly researched in comparison to that of the trade unions,. The few studies that came out were written by employers and were therefore rather personal reflections than in-depth historical analyses. ${ }^{74}$

\section{SINCE THE 1990S: TOWARDS A “GLOBAL” ILO HISTORY?}

There has been a renewed lively research interest in diverse aspects of the ILO since the I990s. I see two reasons for this. Firstly, after the end

69. R. Cox, "Labor and Hegemony", International Organization, 3 I (1977), pp. 385-424. 70. M. Imber, The USA, ILO, UNESCO and IAEA: Politization and Withdrawal in the Specialized Agencies (London, 1989); S. Schlossberg, "United States' Participation in the International Labour Organization: Redefining the Role", Comparative Labor Law Journal (Philadelphia), i I (1989), pp. 48-80; M. Senn, Retrait des Etats-Unis de l'OIT et leur retour an sein de l'organisation: motifs et consequences (unpublished thesis, Hochschule fur Wirtschafts- und Sozialwissenschaften, St Gallen, 1986); W. Galenson, The International Labor Organization: An American View (Madison, WI, I98I); J. Joyce, "Will the USA Quit the ILO?”, Contemporary Review, 228 (1976), pp. I69-I74.

7I. G. Ostrower, "The American Decision to Join the International Labor Organization", Labor History, I6 (1975), pp. 495-504; G. Kruglak, Politics of United States Decision Making in United Nations Specialized Agencies: The Case of the ILO (Washington DC, 1980) about American decision-making and ILO policy-formation between 1954 and I97I.

72. V.-Y. Ghebali, La France en guerre et les organisations internationales, 1939-1945 (Paris, 1969); E. Harari, The Politics of Labor Legislation in Japan: National-International Interaction (Berkeley, CA, I973); V.D. Pedersen, Danmark og De internationale arbejdskonventioner (Arhus, I974); Sverige och ILO, 1927-1977 (Stockholm, I977); J. Mainwaring, International Labour Organization: A Canadian View (Ottawa, I986); F. Blanchard, "La Belgique, les Belges et l'O.I.T.”, in P. Van der Vorst (ed.), Cent ans de droit social belge (Brussels, I988), pp. $857-88$ I; F. de Felice, Sapere e Politica. L'Organizzazione Internazionale di Lavoro tra le due Guerre 1919-1939 (Milan, I988).

73. M. Budiner, Droit de la femme à l'égalité de salaire et la convention nr. 100 de l'Organisation internationale du Travail (Paris, 1975).

74. P. Waline, Un patron au Bureau International du Travail (Paris, 1976); P. Dimitrijevic, L'Organisation internationale $d u$ Travail. Histoire de la représentation patronale (Geneva, 1972). 
of the Cold War and in a new era of globalization nation-states began taking more interest in international policy coordination by multilateral structures. At the same time, the important changes in international society and the global political order revitalized the role of international organizations. These circumstances stimulated the interest of academics in international organizations, given the debate in the literature on the ILO and the social dimension of globalization, the role of international labour standards in the world trade regime, and the creation of core labour standards - these are only a few of today's hot topics. ${ }^{75}$

Secondly, growing research interest in the ILO was also a consequence of the transnationalization of labour history as a field of study. For a long time in the twentieth century labour historians did not look much further than national frames of reference, not paying much explicit attention to international connections, comparisons, and communities. In this scenario they tended to overlook the role of international organizations such as the ILO. But the recent trend towards globalization and the increasing importance of transnational organizations and multinational enterprises broadened labour historians' scope to a transnational or global research level. Studying an organization that was explicitly created to transnationally regulate labour standards and relations automatically opens up the national frameworks of analysis that have traditionally been predominant. The result has been a remarkable boost in the literature. ILO history is now studied from different disciplines and with a wide variety of perspectives and themes related to its long history: for instance women's rights and, more broadly, gender from a constructivist approach, ${ }^{76}$ decolonization, human rights, indigenous and forced labour, ${ }^{77}$ the role of epistemic communities, intellectuals and

75. The literature is huge - here is just one example that also provides a good historical perspective (and is written by an author from the South): M. Nieves Roldan-Confesor, "Labour Relations and the ILO Core Labour Standards", in M. van der Linden and T. Koh (eds), Labour Relations in Asia and Europe (Singapore, 2000), pp. 19-52.

76. E.g. B. Reinalda and N. Verhaaren, Vrouwenbeweging en internationale organisaties I868-1986: een vergeten hoofdstuk uit de geschiedenis van de internationale betrekkingen (De Knipe, 1989); C. Riegelman Lubin and A. Winslow, Social Justice for Women: The International Labor Organization and Women (Durham, NC, 1990); S. Whitworth, "Gender, International Relations and the Case of the ILO”, Review of International Studies, 20 (1994), pp. 389-405; N. Berkovitch, From Motherhood to Citizenship: Women's Rights and International Organizations (Baltimore, MD, 1999); E. Prügl, The Global Construction of Gender: Home-Based Work in the Political Economy of the 2oth Century (New York, 1999).

77. V. Leary, "Lessons from the Experience of the International Labour Organization", in P. Alston (ed.), The United Nations and Human Rights: A Critical Appraisal (Oxford, 1992), pp. 580-620; H.G. Bartolomei de la Cruz, G. Von Potobsky, and L. Swepston, The International Labor Organization: The International Standards System and Basic Human Rights (Boulder, CO, 1996); L. Rodriguez-Piñero, Indigenous Peoples, Postcolonialism, and International Law: The ILO Regime (1919-1989) (Oxford, 2005); D. Maul, Menschenrechte, Sozialpolitik und Dekolonisation. Die Internationale Arbeitsorganisation 1940-1970 (Essen, 2007); idem, "The 
international expertise, ${ }^{78}$ social security and the construction of welfare state regimes, ${ }^{79}$ child labour, ${ }^{80}$ and transnational networks of non-governmental actors and interest group processes, ${ }^{8 \mathrm{I}}$ in many cases looking back to the ideological and political origins ${ }^{82}$ and the early phases (the interwar period for instance) of ILO history. ${ }^{83}$

In order to understand the impact on nation-states of the interplay between state and non-state actors on the international level, some studies have focused on the relations between the ILO and one of its member countries. After all, the ILO is no supranational parliament totally

International Labour Organization and the Struggle against Forced Labour from 1919 to the Present”, Labor History, 48 (2007), pp. 477-500; S. Kott, “Arbeit. Ein transnationales Objekt? Die Frage der Zwangsarbeit im 'Jahrzehnt der Menschenrechte”, in C. Benninghaus et al. (eds), Unterwegs in Europa. Beiträge zu einer pluralen europäischen Geschichte (Frankfurt, 2008, forthcoming).

78. E.g. A. Endres and G. Fleming, International Organizations and the Analysis of Economic Policy, 1919-1950 (Cambridge, 2002); Van Daele, "Engineering Social Peace”, pp. 435-466; S. Kott, "Une 'communauté épistémique' du social? Experts de l'OIT et internationalisation des politiques sociales dans l'entre-deux-guerres", Genèses. Sciences sociales et histoire, 7I (2008), pp. $26-46$.

79. D. Strang and P. Chang, "The International Labor Organization and the Welfare State: Institutional Effects on National Welfare Spending”, International Organization, 47 (1993), pp. 235-262; C. Guinand, Die Internationale Arbeitsorganisation (ILO) und die soziale Sicherheit in Europa (1942-1969) (Berne, 2003); I. Liebeskind, L'Organisation internationale du Travail face au chômage: compétences normatives et contribution à l'évolution de la pensée économique, 1919-1939 (unpublished doctoral dissertation, Geneva University, 2005); D. Maul, "Der transnationale Blick. Die Internationale Arbeitsorganisation und die sozialpolitischen Krisen Europas im 20. Jahrhundert”, Archiv für Sozialgeschichte, 47 (2007), pp. 349-369.

80. M. Dahlén, The Negotiable Child: The ILO Child Labour Campaign 1919-1973 (Uppsala, 2007).

8 . E. Lorenz, Defining Global Justice: The History of US International Labor Standards Policy (Notre Dame, IN, 200I).

82. Van Daele, "Engineering Social Peace"; R. Tosstorff, "The International Trade-Union Movement and the Founding of the International Labour Organization”, IRSH, 50 (2005), pp. 399-433; M. Rodriguez Garcia, "Early Views on Internationalism: Marxist Socialists versus Liberals", Labour Internationalism: Different Times, Different Faces (special issue Revue belge de Philologie et d'Histoire), 84 (2006), pp. 1049-1073.

83. L. Heerma van Voss, "The International Federation of Trade Unions and the Attempt to Maintain the Eight-Hour Working Day (1919-1929)", in F. van Holthoon and M. van der Linden (eds), Internationalism in the Labour Movement, I830-1940 (Leiden, I988), pp. 518-542; S. Grabherr, Das Washingtoner Arbeitszeitübereinkommen von 1919. Versuch einer internationalen Regelung der Arbeitszeit in Europa (Berlin, I992); J. Heitmann, "The ILO and the Regulation of White Lead in Britain during the Interwar Years: An Examination of International and National Campaigns in Occupational Health", Labour History Review, 69 (2004), pp. 267-284; T. Cayet, Organiser le travail, organiser le monde. Etude d'un milien international d'organisateurs-rationalisateurs durant l'entre-deux-guerres (unpublished doctoral dissertation, European University Institute, 2005); P.-A. Rosenthal, "Géopolitique et Etat-providence. Le BIT et la politique mondiale des migrations dans l'entre-deux-guerres”, Annales HSS, 6I (2006), pp. 99-I34. 
independent from the nation-states. National governments finance the activities of the ILO and are supposed to implement its international labour standards. A few external researchers, often financed by their national governments, took the occasion of the ILO's seventy-fifth anniversary in 1994 to undertake national case studies of the ILO from a historical perspective. ${ }^{84}$ What these studies have in common is that they are mainly based on national archives. By not systematically exploring the international archives in Geneva they do not unravel the complexity of the context of the ILO as an international organization. Other studies have tried to overcome these shortcomings. They consider nation-states not as dominant units in world politics, but use national case studies for the analysis of the development and the real impact of the ILO as creator or disseminator of ideas and policies. ${ }^{85}$

Drawing general conclusions based on all these studies would do harm to this wide range of multifaceted scholarship, but if there is one common thread that can be detected, then it is the broader contextual frame of reference in which the ILO is analysed. The deterministic and structuralist approach of political scientists in the I960s and I970s, who studied the ILO as a rather closed political system that left no room for agency and social change, was abandoned. In recent research the ILO is no longer solely regarded as a decision-making arena for nation-states, but rather as a potentially dynamic intellectual actor where long-term social change is or could be effected: in other words, as an international organization for the conceptualization, diffusion, and transmission of ideas and policies on labour issues in a broader transnational network of diverse actors, governmental and non-governmental, policy-makers, technical experts, and interest groups acting beyond the nation-state.

The wide variety of subjects, as well as the perspective of the ILO as creator or disseminator of ideas and policies, were clearly reflected in the "ILO: Past and Present" conference, organized in Brussels in October 2007.

84. K. Ewing, Britain and the ILO (London, 1994); H. Heldal, Norge i ILO 1919-1939: Norske statsmyndigheters, arbeidsgiveres og fagforeningers holdning til den internasjonale arbeidsorganisasjon (Oslo, 1994); a summary in English appeared as H. Heldal, "Norway in the International Labour Organization, I919-1939”, Scandinavian Journal of History, 2 I (1996), pp. 255-283; J. Cuesta Bustillo, Una esperanza para los trabajadores. Las relaciones entre España y la Organización Internacional del Trabajo (1919-1939) (Madrid, I994).

85. S. Hughes, New Zealand and the ILO: Current Debates and Future Direction (Auckland, 1995); K. Boonstra, The International Labour Organization and the Netherlands: Different Views concerning Government Influence on the Relationship between Workers and Employers (Leiden, I996); M. Ruotsila, "The Great Charter for the Liberty of the Workingman: Labour, Liberals and the Creation of the ILO", Labour History Review, 67 (2002), pp. 29-47; J. Van Daele, "Engineering Social Peace: The ILO as a Laboratory for the Transnational Transfer of Ideas and the Influence on Social Politics in Belgium 1919-1944" (in Dutch) (unpublished doctoral dissertation, Ghent University, Department of Contemporary History, 2007). 
This was the first international academic forum ever organized that was entirely devoted to ILO history. The ILO's origins and past and present achievements, failures, objectives, and future potential were assessed from a multidisciplinary perspective, albeit largely dominated by social historians. The papers presented at the conference both revisited old terrains (for instance the role of the socialist International Federation of Trade Unions, World War II, the economic depression and unemployment, and the role of the ILO's Directors-General) and provided new facts on ILO history (for instance on the ILO's response to political authoritarianism in Latin America and eastern Europe). Other papers dealt with topics as varied as metropolitan and non-metropolitan labour, decolonization, child labour, and explored issues that have often been neglected in traditional ILO literature: for instance, the efforts of internationally organized women and of intellectual workers to find a place within the ILO. ${ }^{86}$ The broad scope of the conference also made it possible to evaluate the ILO's challenges from the global political economy of the last decades. Jeffrey Harrod, for example, critically assessed the ILO's tripartite model of labour relations that, dating back to I919, has only represented the formal trade-union organizations and leaves no room for the growing informal sector. However, despite the wide variety of topics, the Brussels conference suffered from the same old shortcomings. Except for two contributions on Latin America and a few others on nonmetropolitan labour, welfare reform in the South, and the already mentioned informal sector, the majority of the contributions focused entirely on the industrialized world. Unfortunately, one has thus to conclude that ILO history is still not "global history".

It is clear from this overview that academic and, more specifically, historical scholarship has taken over the leading role from the "insider" literature of the early decades. This does not mean that historical studies produced by the ILO itself have completely disappeared. The seventy-fifth anniversary in 1994 was once more an occasion to look at the organization's past, ${ }^{87}$ including some good reviews of the Declaration of Philadelphia in I944. ${ }^{88}$

86. See also M. Rodriguez Garcia, "Conference Report 'The International Labor Organization: Past and Present”, International Labor and Working-Class History, (2008) (forthcoming). A book with a selection of the papers is under preparation for publication in 2009 .

87. "75th anniversary issue", ILR, I33 (1994), pp. 431-522; Visions of the Future of Social Justice: Essays on the Occasion of the ILO's 75th Anniversary (Geneva, 1994); "International Labor Organization's 75th Anniversary”, Monthly Labor Review, I I7:9 (1994), pp. 3-58; B. Brett, International Labour in the 2 Ist Century: The International Labour Organization, Monument to the Past or Beacon for the Future? (London, I994).

88. E. Lee, "The Declaration of Philadelphia: Retrospect and Prospect", ILR, I33 (I994), pp. 467-484; J.D. French, "The Declaration of Philadelphia and the Global Social Charter of the United Nations, 1944/45", in Sengenberger and Campbell, International Labour Standards, pp. 19-27. 


\section{LONG-TERM SHIFTS AND FUTURE CHALLENGES}

ILO history as a field of study has had its ups and downs over the past ninety years. Different shifts and general characteristics help to explain the current state of the field. Firstly, the relationship between "inside" and "outside" literature on ILO history has changed significantly over the course of time. Originally, ILO staff paved the way, which resulted in the classical institutional history, an official account of organizational development and a summing-up of the major working fields, often for commemorative purposes. Legal scholars and political scientists gradually took over for a long period, before professional historians came into the picture, stimulated by a trend towards a more academic (since the I950s and I960s) and globalizing labour history (since the I990s). This professionalization in ILO history broadened as well as deepened ILO historiography. The focus shifted away from the "architecture" of the ILO and its procedures towards the broader transnational context and the networks of actors in which the ILO was functioning.

Consequently the gap between in-house and scholarly attention to the ILO has widened over the course of time. This is a second shift. Whereas in the early decades it was not at all unusual that books written on the ILO by academics were prefaced by the ILO's Director, the ILO's knowledge of its own past (as well as knowledge of academic developments regarding the history of the ILO) has become gradually limited in more recent decades. The classic studies of Ernst Haas and Robert Cox exemplify this evolution. Bridging the gap between in-house and academic attention towards the ILO is therefore a real challenge for the recently launched ILO Century Project, involving both ILO staff and academic scholars. ${ }^{89}$ Not surprisingly, this project also has a strong commemorative dimension, looking forward to the centenary in 20I9. A first stage in this project will commemorate the ninetieth anniversary in 2009 , focusing on the impact of ILO ideas on social development.

Scientific research into an international organization such as the ILO cannot be undertaken in a vacuum, but has to take into account the international context at the time. Thirdly, the assumption that "the fate of the field reflects the fate of the world" is, in the case of the ILO, certainly true for the period up to World War II (an explosion of work after I9I9, followed by a period of more cautious reassessment approaching the I930s) and for recent decades, but definitely not for the postwar period until the late i960s. The heyday of the Cold War, in an international context of East-West tension, stimulated a more critical and analytical approach to research on the ILO.

89. For more information on this project see http://www.ilocentury.org. 
The fourth conclusion is that ILO historiography suffers from "geographical narrowness". Although the ILO is an international organization that explicitly aims to promote minimum labour standards worldwide, ILO historiography has been, until now, largely dominated by scholars from the the North Atlantic and the developed world. This is, of course, no coincidence. Between the two world wars, the ILO was largely dominated by European countries and in this period the literature definitely is a reflection of this "old boys' network" of European founding fathers. While a lot of attention was paid to the United States and the Soviet Union, related to the problems of universal membership and the case of freedom of association in the context of the Cold War, there was for a long time no comparable interest in the regions in the South, although the ILO significantly expanded its membership to a large group of developing countries after decolonization. India is to a certain extent an exception, but here too, the field was largely dominated by people personally related to the work and world of the ILO. Overall, the ILO's role and regional activities in the non-Western world still need a lot of further in-depth research. Here the problem of the availability and accessibility of sources comes into the picture. In my opinion, written sources, only to a certain extent available in ILO regional offices, should be combined with oral sources. In recent years, oral history has become popular for research into the southern hemisphere, with the encouragement of the International Institute of Social History, for example.

Turning to new research paths in ILO history, one topic could be an investigation into the impact of ILO regional offices on the regions, as well as on headquarters policy in Geneva. In South Africa this could be tested for the case of apartheid, in which the ILO took on the protection of black workers. South Africa was forced out of the ILO in 1963 after a period of moves by African delegates to condemn the country for its ongoing apartheid. In connection with this, an interesting enquiry could be into what ways events within the ILO contributed to the UN launching the convention on the elimination of racial discrimination in 1965 . This leads on to the question of relations between the ILO and other international organizations, governmental as well as non-governmental, at the global level. In this perspective, a history of the ILO and global migration, by integrating the story of the International Migration Organization,,$^{\circ}$ would be a challenge

90. The International Organization for Migration was established in $195 \mathrm{I}$ as the Provisional Intergovernmental Committee for the Movement of Migrants from Europe (PICMME) to help resettle displaced people in the chaos after World War II. Based in Geneva, it is now the principal intergovernmental agency promoting the humane management of migration and protecting migrants' rights by international cooperation and facilitating and regulating international migration; M. Ducasse-Rogier, The International Organization for Migration I95I-200I (Geneva, 200I). 
for labour historians. And within the realm of development studies, a history of the ILO and global development strategies in the long run opens up other interesting research paths (e.g. from the ILO Andean programme of the late I940s through the World Employment Program in the early I970s to the recent Decent Work Agenda). In this case the emphasis would be on technical cooperation, strongly under-researched in comparison with the ILO as as a standard-setting organization..$^{91}$

There are, of course, a lot of other missing pieces in the puzzle of ILO history. Looking at the unequal treatment of the ILO tripartite constituents, there is definitely an urgent need for in-depth academic research on the employers' side that has been far less studied than the role of trade unions. It is significant that in recent years only one overview - rather a coffee-table book on the institutional development of the International Organization of Employers than a thorough historical analysis - was brought out by an old President of the OIE..$^{2}$ Consequently, it will come as no surprise that the ILO and multinational corporations is a blank research field.

Within the broader network of transnational actors a lot has been said about labour and to a lesser extent liberal internationalism. On the side of Catholic social organizations, research on the ILO and the Christian working class is far less popular. ${ }^{93}$ One reason is the dominance of the socialist International Federation of 'Trade Unions in the ILO's Workers' Group in the first half of the twentieth century. In this light it would be interesting to know more about the (development of the) relationship between the ILO and the Catholic Church, after all both universalinternational organizations. Formal relations with the Vatican were established initially by the ILO's first Director, Albert Thomas, in the early i 920 s. ${ }^{94}$ Of the ILO and other world religions (and the quite powerful freemasonry in international circles) virtually nothing is known.

Given the evident problems with common sources, here again oral history would be very helpful, as it would be for analysis of electoral politics in the ILO (and international organizations in general). The campaigns led by candidates running for Director-General, for instance,

91. J.M. Bonvin, L'Organisation internationale du Travail. Etude sur une agence productrice de normes (Paris, I998); K. Basu (ed.), International Labor Standards: History, Theory, and Policy Options (Malden, MA, 2003).

92. J.J. Oechslin, The International Organization of Employers: Three-Quarters of a Century in the Service of the Enterprise (1920-1998) (Geneva, 200I).

93. An exception is P. Pasture, Histoire du syndicalisme chrétien international. La difficile recherche d'une troisième voie (Paris, I999).

94. G. Thélin, '... Pratique la justice'. Le christianisme social et l'Organisation internationale du Travail (Paris, I939); A. Arnou, Organisation internationale du Travail et les catholiques (Paris, 1933); A. Le Roy, Catholicisme social et Organisation internationale du Travail (Paris, 1937), trans. in English as A. Le Roy, Catholics and the International Labor Organization (New York, 1939). 
leave practically no traces in the archives. It is here that memoirs and (auto)biographies of (former) ILO officials and Directors-General could be useful. ${ }^{95}$ The biographical genre especially offers an interesting insight into organizations. ${ }^{96}$ Representatives of national governments, trade-unionists, employers and - even more - officials in international bureaucracy are very often represented as invisible and anonymous actors promoting social change. Biographies give these actors a "human face" by throwing light on the people struggling with their idea(l)s and minor shortcomings within an international context. Albert Thomas has always been a rewarding subject for biographers. ${ }^{97}$ Currently a biography on David Morse, ILO Director-General between 1948 and 1970, is being completed..$^{8}$ Morse's successor, Wilfred Jenks, is, however, still waiting for an academic biographer. Although very briefly in charge (as DirectorGeneral between I970 and I973), he had a life-long career in the ILO, producing a long series of interesting writings, not only on the ILO but with a much wider and theoretical perspective on international relations that deserves more attention from historians and other researchers interested in the history of the ILO. ${ }^{99}$

Overall, in writing the history of the ILO, it is crucial never to lose sight of the organization's main subject, working people themselves. Ignoring in our research the basic question of what the ILO ultimately meant for the working conditions and lives of millions of men, women, and children worldwide results in a dry institutional historiography devoid of its human link to the real world of work.

95. E.g. A.A. Agard Evans, My Life as an International Civil Servant in the International Labour Organization (Geneva, I995) (covers historical aspects of the ILO from I929 to I966); M. Hansenne, Un garde-fou pour la mondialisation. Le BIT dans l'après-guerre froide (Gerpinnes [etc.], I999); F. Blanchard, L'Organisation internationale du Travail. De la guerre froide à un nouvel ordre mondial (Paris, 2004).

96. J. Van Daele, Van Gent tot Genève. Louis Varlez. Een biografie (Ghent, 2002); Female officials are, of course, even less the subject of research. Françoise Thébaud (University of Avignon) is currently working on a biography of Marguerite Thibert, an ILO official in the I 920 s as an expert on women's labour.

97. Other than the already cited literature: M. Fine, “Albert Thomas: A Reformer's Vision of Modernization”, Journal of Contemporary History, I 2 (1977), pp. 545-564; D. Guerin, Albert Thomas an BIT: de l'internationalisme à l'Europe (Geneva, 1996).

98. D. Maul, Modernization, Democracy and Social Justice in the American Century: The Life of David A. Morse, $1907-1990$ (in preparation).

99. E.g. C.W. Jenks, The World Beyond the Charter in Historical Perspective (London, 1969); idem, Social Policy in a Changing World: The ILO Response (Geneva, 1976). 